\title{
Title:
}

\section{McKittrick-Wheelock syndrome: rectal villous adenoma as a cause of acute renal failure}

\section{Authors:}

Carlos Ordieres Díaz, Isabel Pérez Valle, Margarita Fernández de la Varga, Pedro Amor Martín, Marta Álvarez Posadilla, Ángel Cano Abascal, Adrián Huergo Fernández

\section{DOI: $10.17235 /$ reed.2022.8518/2021}

Link: PubMed (Epub ahead of print)

Please cite this article as:

Ordieres Díaz Carlos, Pérez Valle Isabel, Fernández de la Varga Margarita, Amor Martín Pedro, Álvarez Posadilla Marta, Cano Abascal Ángel, Huergo Fernández Adrián. McKittrick-Wheelock syndrome: rectal villous adenoma as a cause of acute renal failure. Rev Esp Enferm Dig 2022. doi: 10.17235/reed.2022.8518/2021.

This is a PDF file of an unedited manuscript that has been accepted for publication. As a service to our customers we are providing this early version of the manuscript. The manuscript will undergo copyediting, typesetting, and review of the resulting proof before it is published in its final form. Please note that during the production process errors may be discovered which could affect the content, and all legal disclaimers that apply to the journal pertain. 
CC 8518

McKittrick-Wheelock syndrome: rectal villous adenoma as a cause of acute renal failure

Carlos Ordieres Díaz ${ }^{1}$, Isabel Pérez Valle ${ }^{1}$, Margarita Fernández de la Varga ${ }^{1}$, Pedro Amor Martín ${ }^{1}$, Marta Álvarez Posadilla ${ }^{1}$, Ángel Cano Abascal ${ }^{2}$, and Adrián Huergo Fernández $z^{1}$

${ }^{1}$ Digestive System Clinical Management Unit, and ${ }^{2}$ Department of Neurology. Hospital Vital Álvarez Buylla. Mieres, Asturias. Spain

Correspondence: Carlos Ordieres Díaz

e-mail: c_ordieres@hotmail.com

Keywords: Villous adenoma. Diarrhea. Acute renal failure. Mckittrick-Wheelock syndrome.

Conflict of interest: the authors declare no conflict of interest.

Dear Editor,

We report the case of a 67-year-old male with a history of arterial hypertension and atrial fibrillation, who was admitted for acute renal failure (creatinine: $4.41 \mathrm{mg} / \mathrm{dl}$ ) and hypotension. He also presented hyponatremia (129 mmol/L) and hypokalemia (2.7 $\mathrm{mmol} / \mathrm{L}$ ). The patient referred profuse diarrhea during the previous two months as a possible triggering cause. Physical examination showed signs of dehydration and palpation of a polypoid mass in the rectal ampulla. Colonoscopy revealed a villous lesion (LST-G Is-Ila, Paris classification) extending from the anal margin, involving the entire circumference, to about $15 \mathrm{~cm}$ away of the anal margin, which was unresectable 
endoscopically (Fig. 1). The histopathological analysis of the biopsies was compatible with villous adenoma with areas of severe dysplasia. An abdominoperineal resection was performed, and the surgical specimen was reported as well-differentiated adenocarcinoma of the rectum on a villous lesion that did not affect the muscularis propria, and with no lymph node involvement. In a subsequent review the patient was asymptomatic, with normalization of laboratory parameters.

\section{DISCUSSION}

McKittrick-Wheelock syndrome (1) is defined as hypersecretory diarrhea with hydroelectrolyte depletion associated with villous adenoma of the rectum. Hypersecretion is thought to be produced by overexpression of prostaglandin E2 in this type of lesion (2). Cases can be very severe and lead to hypovolemic shock, so first-line treatment involves hydroelectrolytic and acid-base balance correction (3). Treatment with indomethacin or somatostatin may be considered to decrease hypersecretion. It is also worth mentioning that this syndrome is highly associated with invasive cancer, with adenoma size and extension being the main risk factors. Thus, resection of the lesion is considered the definitive treatment (4).

\section{REFERENCES}

1. McKittrick LS, Wheelock FC. Carcinoma of the colon. 1954. Dis Colon Rectum 1997;40(12):1494-5. DOI: 10.1007/BF02070718

2. López-Fernández J, Fernández-San Millán D, Navarro-Sánchez A, et al. McKittrick-Wheelock syndrome: A rare cause of metabolic coma. Gastroenterol Hepatol 2017;40(5):349-51. DOI: 10.1016/j.gastrohep.2016.04.002

3. Fernández-López F, Paredes-Cotore JP. McKittrick-Wheelock syndrome prolapsed giant villous adenoma of the rectum. Rev Esp Enferm Dig 2013;105(5):309-10. DOI: 10.4321/s1130-01082013000500017

4. Valentí $\mathrm{V}$, Hernández-Lizoáin JL, Gil A, et al. Adenoma velloso hipersecretor de recto. Diagnóstico y tratamiento [Secreting villous adenoma. Diagnosis and 


\section{ENFERMEDADES DIGESTIVAS}

The Spanish Journal of Gastroenterology

treatment]. Rev Esp Enferm Dig 2005;97(3):215-6. DOI: $10.4321 / \mathrm{s} 1130-01082005000300012$

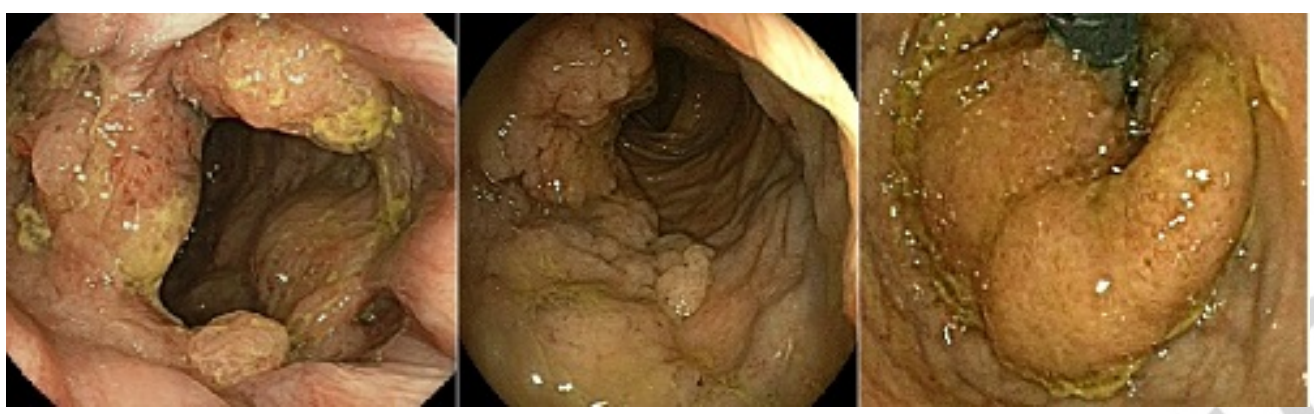

Fig. 1. Endoscopic images in front view and retroflexion. 